\title{
鉄筋コンクリートに生じる内部ひび割れの 可視化に関する実験的および解析的検討
}

\author{
車谷 麻緒 $^{1} \cdot$ 邊見 哲一 ${ }^{2} \cdot$ 岡崎 慎一郎 3 \\ 1正会員 茨城大学 工学部 都市システム工学科（† 316-8511 茨城県日立市中成沢町 4-12-1） \\ 2学生会員 茨城大学大学院 理工学研究科都市システム工学専攻（† 316-8511 茨城県日立市中成沢町 4-12-1) \\ 3 正会員 香川大学 工学部 安全システム建設工学科（T 761-0396 香川県高松市林町 2217-20）
}

\begin{abstract}
本論文では，鉄筋コンクリートに発生する内部ひび割れの形状や開口幅を計測することが可能な試験体およ び試験方法を提案し，その妥当性を検証する．提案する試験体は，鉄筋を一部露出させることで，鉄筋近傍に 発生する内部ひび割れの直接計測が行える RC はりである.はじめに，ひび割れの 3 次元幾何形状を再現でき る数值解析を用いて，提案する試験体において内部ひび割れが適切に発生することを検証する．次に，実際に 作成した試験体に対して載荷実験を行い，デジタル画像相関法を用いてひずみ分布を計測し，試験体に発生し たひび割れを可視化する．そして，画像相関法により計測したひび割れと数值解析により再現したひび割れを 比較することで，提案する試験体および試験方法により，内部ひび割れの可視化が可能であることを示す.
\end{abstract}

Key Words: internal crack, reinforced concrete beam, digital image correlation, damage model, FEM

\section{1.はじめに}

鉄筋コンクリートは，引張に弱いコンクリートを鉄 筋が補強すると同時に, 腐食しやすい鉄筋をコンクリー トが保護することで成立している．ただし，鉄筋により 補強されているとはいえ，引張を受けるコンクリート にはひび割れが入ることをある程度許容している．コ ンクリートのひび割れは, 外力のほかに, 温度変化や 乾燥による構成材料の体積変化などによっても発生す る.ひび割れは, 水やイオンの通り道となり, 鉄筋腐食 など様々な劣化を引き起こし, 鉄筋コンクリートの耐 久性を低下させる. 鉄筋コンクリートにおける設計時 での塩害の照査では, コンクリートの水セメント比や かぶり厚さのほかに, 表面ひび割れの開口幅, 供用年 数などを用いた評価式を用いてもよいとされている ${ }^{1)}$.

鉄筋コンクリートに発生するひび割れには，コンク リート表面から発生するひび割れのほかに, 鉄筋の近傍 から発生し, 表面に現れないひび割れが存在する。これ

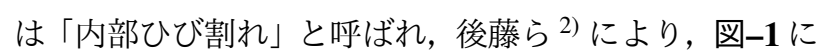
示すように，その形状や発生メカニズムが明らかにさ れている.内部ひび割れは, 鉄筋応力が $100 \mathrm{MPa}$ 程度 の場合でも発生するという研究報告 ${ }^{2)}$ から, 現在供用 されている多くの RC 構造物の内部において発生して いると考えられる. 内部ひび割れは， RC 部材の変形性 能や付着機構と密接に関係することに加えて ${ }^{6), 7)}$, 既往 の研究では, 内部ひび割れは表面ひび割れと同様に, 水 やイオンの移動を加速させると考えられている ${ }^{3), 4), 5) . ~}$

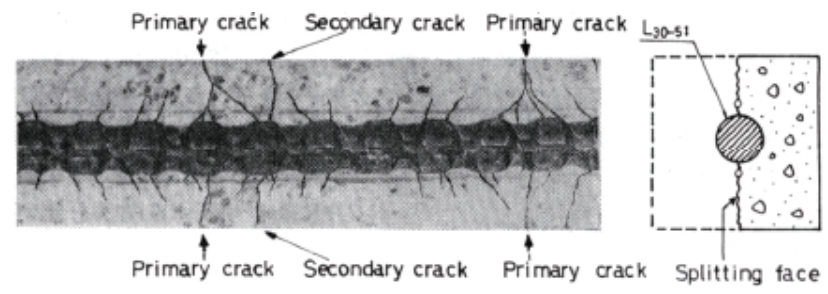

図-1 異形鉄筋の周辺に形成する内部ひび割れ 2)

しかし, 発生位置が内部であることから，一般に内部 ひび割れの計測は困難である。そのため, 内部ひび割 れが鉄筋コンクリートの劣化に与える影響は詳しく検 討されておらず，劣化に関する評価式にも内部ひび割 れは考慮されていない.

内部ひび割れを計測する方法のひとつに，インク注 入法と呼ばれるものがある。これは, 試験中に発生し たひび割れにインクを注入し, 染色することで, 内部 ひび割れを可視化する方法である。これまでに，イン ク注入法を用いて，コンクリート内部に発生する様々 ひび割れを可視化した研究が報告されている 2),8),9). た，インクの替わりに造影剤をひび割れに注入し，X 線撮影によりひび割れの 3 次元形状を把握する研究も 行われている ${ }^{10)}$. インク注入法は内部ひび割れの可視 化に有効な手法であるが，染色された内部ひび割れを 計測するには, 当然のことながら, 試験体を切断しな くてはならない. そのため, 載荷過程における内部ひ び割れの発生状況や進展度合を観察することができず, 
試験終了後の除荷後における内部ひび割れしか計測す ることができない，一方で，かぶり厚さをほぼ 0 とし た試験体を用いて, 試験体表面に表れた内部ひび割れ を計測し, 内部ひび割れの位置や発生間隔を調べた研 究 ${ }^{11), 12)}$ がある. しかし，この方法では試験体に特殊な 拘束を与えているため, 厳密には RC 部材の内部の状 態とは異なっている．また，鉄筋自体を見ることがで きないため, 内部ひび割れの発生と鉄筋形状との関係 性ついても確認することができない。

これに対して, 著者ら ${ }^{13)}$ は, 既往の研究において, 片側のかぶりを取り除き, 表面に鉄筋を露出させた特 殊な試験体を提案し, 両引試験を行うことで, 載荷過 程における内部ひび割れの発生や進展の直接計測を行っ た。これにより, 載荷過程における内部ひび割れの計 測が可能になったものの, 計測された内部ひび割れの 形状は, 後藤らが示したものとは少し違っていた。そ の原因として, 試験体のかぶりを片側のみ取り除いた ため, 試験体の対称性が失われ, 試験体に引張が適切 に作用せず，実際の RC 部材とは異なる応力状態になっ たと考えられる.

そこで本研究では, 試験体の対称性を維持しつつ, 鉄 筋を露出させた試験体を用いて, 内部ひび割れを直接 計測することが可能な試験方法を提案する.はじめに, 提案する試験体の概要を説明した後, ひび割れの 3 次 元幾何形状を再現できる数值解析 ${ }^{14)}$ 用いて, 鉄筋を 露出させた試験体において内部ひび割れが適切に発生 することを検証する. 次に, 実際に作成した試験体に 対して載荷実験を行い, デジタル画像相関法 ${ }^{15)}$ を用い てひずみ分布を計測し, 試験体に発生したひび割れを 可視化する. そして, 画像相関法により計測（可視化） したひび割れと数值解析により再現したひび割れを比 較することで, 提案する試験体の妥当性を検証する.

\section{2. 提案する試験体および試験方法}

内部ひび割れは，引張が作用する $\mathrm{RC}$ 部材において， 異形鉄筋の節がコンクリートを押し出すことにより, 部 材の内部で発生する.つまり, 内部ひび割れを実験で再 現するには, RC 試験体に引張を作用させる必要がある. 既往の研究で多く用いられてきた試験体は, 図-2 (a)に 示すように，コンクリートブロックの中央に鉄筋を配 置し，鉄筋を引張ることにより，内部ひび割れを発生 させている，しかし，鉄筋が試験体の中央に埋め込ま れているため, 内部ひび割れの進展過程を直接計測す ることができない.

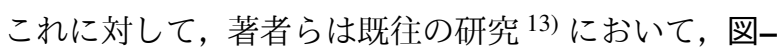
2 (b) に示すように, この試験体の片側のかぶりを除去 し，鉄筋を片側のみ露出させた試験体を考案した。し

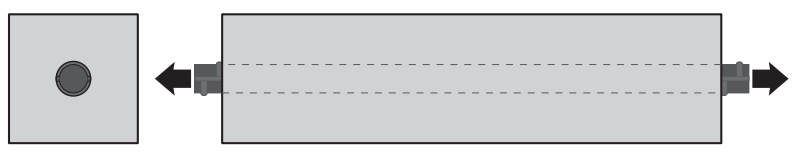

(a) Tensile test specimen with a bar arranged in center

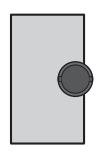

(b) Tensile test specimen with a bar exposed partially

図-2 先行研究 ${ }^{2), 13)}$ における試験体
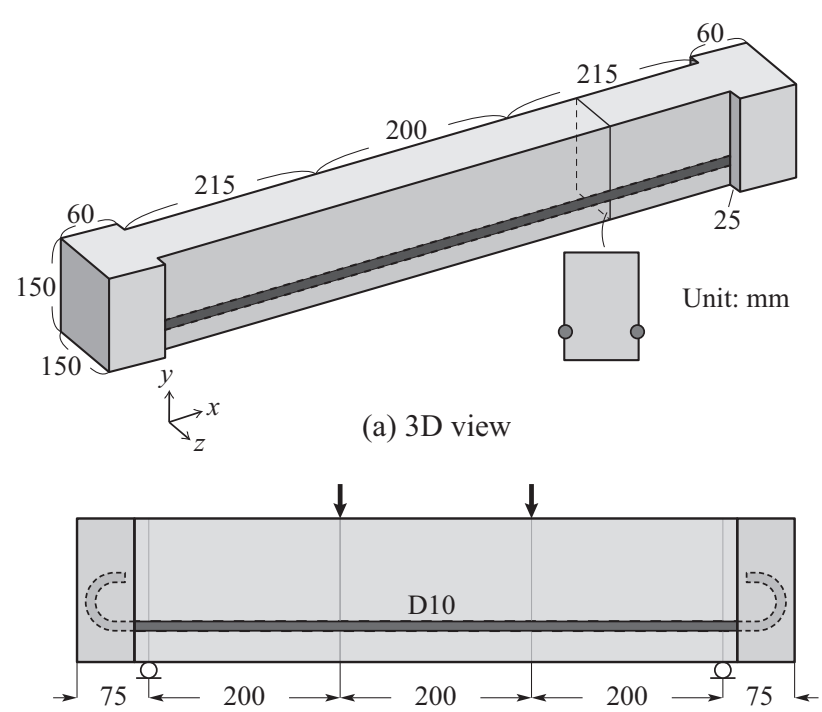

(b) $x-y$ view

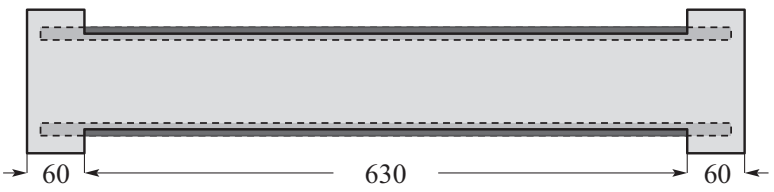

(c) $z-x$ view

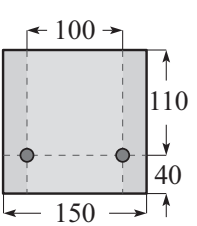

(d) $y$ - $z$ view

図-3 本論文で提案する試験体

かし，引張試験によって鉄筋まわりに発生したひび割 れは, 後藤らが示した内部ひび割れの形状とは異なっ ていた．その原因として，片側のかぶりのみを除去し たことで, 試験体の対称性が失われたため, 試験体に 引張が適切に作用しなかったと考えられる. よって, 内 部ひび割れを実験で適切に再現するには, 試験体の対 称性を失わせないことと, 試験体に引張を適切に作用 させることが重要となる. 
そこで本研究では，まず，図-3に示すように，鉄筋 を 2 本配置し，両側面のかぶりを取り除いた試験体を 提案する。こうすれば，試験体の対称性を保った状態 で, 鉄筋を試験体表面に露出させられるので, 内部ひ び割れを直接計測することができる，ただし，鉄筋を 2 本配置した試験体では, 引張試験において，2 本の鉄 筋を均等に引張ることが難しく, 内部ひび割れの発生 に問題が生じる可能性が高い。そこで本研究では, 引 張試験によって試験体に引張を作用させるのではなく, 曲げ試験によって曲げモーメントを発生させ, 曲げ応 力による引張を試験体に作用させる。こうすれば, 試 験体の対称性を保った状態で, 試験体に引張を作用さ せることができ, 露出させた鉄筋の近傍において内部 ひび割れを発生させられる.

実際の試験体は, 図-3 (b), (c) に示すように, 鉄筋を 固定するため, 試験体の両端部にはかぶりを設けてお く.さらに，付着力の低下による鉄筋の引き抜きを防 止するため, 主鉄筋の端部には標準フックを設ける.

提案する試験体では, かぶりを部分的に取り除いた ことで，鉄筋が完全に埋め込まれた実際の RC 部材と厳 密には同じ応力状態にはならない, 以降の章では, 数 值解析と画像解析を用いて, 提案する試験体の鉄筋ま わりに, 図-1 と同じ特徵を有する内部ひび割れが形成 することを検証する.

\section{3. 数値解析による検証}

実際に試験体を作成して，実験を行う前に，ひび割 れの 3 次元幾何形状を再現できる数值解析 ${ }^{14)}$ を用いて, 提案する試験体において内部ひび割れが適切に発生す るかどうかを検証する. はじめに, 数值解析の定式化を 示した後, 図-3 と同様の有限要素モデルに対して, 数 值実験を行い, 内部ひび割れの再現性を検証する.

\section{(1) 数值解析の定式化}

\section{a) 支配方程式}

弾性限界後に塑性変形する領域と, 損傷する領域で 構成される二相材料のつり合い問題を考える. 平衡方 程式, ひずみの適合条件式, 応力ーひずみ関係式は, そ れぞれの次のように表される。

$$
\begin{array}{cc}
\nabla \cdot \boldsymbol{\sigma}+\overline{\boldsymbol{b}}=\mathbf{0} & \text { in } \Omega \\
\boldsymbol{\varepsilon}=\frac{1}{2}\left\{\nabla \boldsymbol{u}+(\nabla \boldsymbol{u})^{\mathrm{T}}\right\} & \text { in } \Omega \\
\boldsymbol{\sigma}=\hat{\boldsymbol{\sigma}}(\boldsymbol{\varepsilon}) & \text { in } \Omega
\end{array}
$$

ここで, $\sigma$ は Cauchy 応力テンソル, $\varepsilon$ は微小ひずみテ ンソル, $\boldsymbol{u}$ は変位ベクトル, $\overline{\boldsymbol{b}}$ は既知の物体力ベクトル, $\nabla$ はナブラ演算子, $\Omega$ は物体領域である. $\hat{\sigma}$ は各相の 材料挙動を規定する構成則関数である.

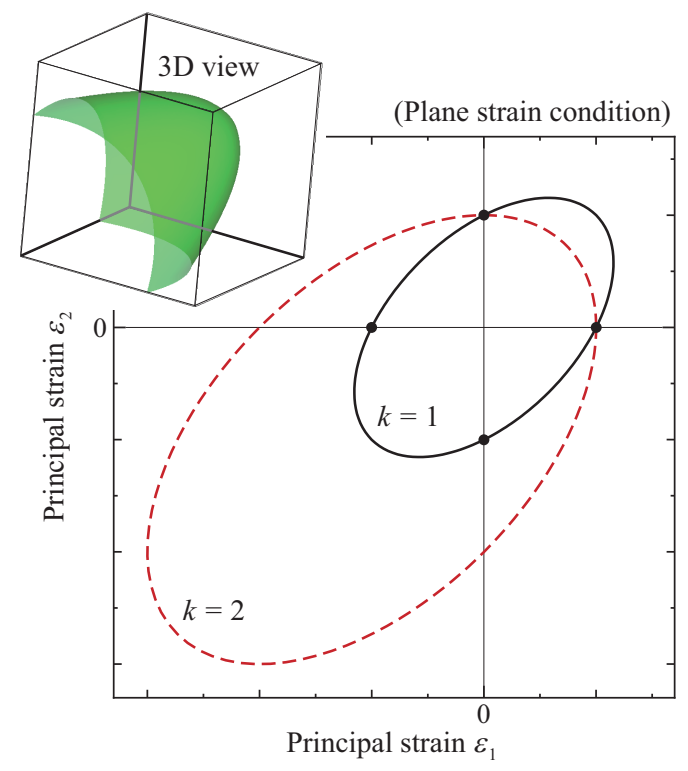

図-4 主ひずみ空間における等価ひずみの等値面

変位が規定されるディリクレ境界 $\Gamma_{u}$ と表面力が規定 されるノイマン境界 $\Gamma_{t}$ では, 次の条件が課される.

$$
\begin{array}{cc}
\boldsymbol{u}=\overline{\boldsymbol{u}} & \text { on } \Gamma_{u} \\
\boldsymbol{t}=\boldsymbol{\sigma} \boldsymbol{n}=\overline{\boldsymbol{t}} & \text { on } \Gamma_{t}
\end{array}
$$

ここで, $\boldsymbol{t}$ は外向き単位法線ベクトル $\boldsymbol{n}$ で規定される面 における単位面積当たりの表面力ベクトル, $\bar{t}$ は既知の 表面力ベクトルである.

仮想変位ベクトルを $\delta \boldsymbol{u}$ とし, 平衡方程式を弱形式化 すると次のようになる.

$\int_{\Omega} \nabla \delta \boldsymbol{u}: \sigma d \Omega=\int_{\Omega} \delta \boldsymbol{u} \cdot \overline{\boldsymbol{b}} d \Omega+\int_{\Gamma_{t}} \delta \boldsymbol{u} \cdot \overline{\boldsymbol{t}} d \Gamma \quad \forall \delta \boldsymbol{u}(6)$

\section{b) 鉄筋の材料モデル}

本研究では, 鉄筋の構成モデルに von-Mises 塑性モ デルを適用する，そして，次に示すように，全ひずみ は弾性ひずみと塑性ひずみに加算分解され, 応力は弾 性成分のみが寄与するものとする.

$$
\begin{gathered}
\varepsilon=\varepsilon^{\mathrm{e}}+\varepsilon^{\mathrm{p}} \\
\sigma=c: \varepsilon^{\mathrm{e}}=c:\left(\varepsilon-\varepsilon^{\mathrm{p}}\right)
\end{gathered}
$$

ここで, $\varepsilon$ は微小ひずみテンソル,$\varepsilon^{\mathrm{e}}$ は弾性ひずみテ ンソル, $\varepsilon^{\mathrm{p}}$ は塑性ひずみテンソル, $\sigma$ は Cauchy 応力テ ンソル, $\boldsymbol{c}$ は弾性テンソルである.

指数関数で与えられる非線形等方硬化則 ${ }^{16)}$ を採用す ることにより, 降伏関数 $f \leq 0$ は次式で与えられる.

$$
f=\sigma_{\mathrm{v}}-\sigma_{\mathrm{y} 0}-Q\left(1-e^{-b p}\right)
$$

ここで, $\sigma_{\mathrm{v}}$ は von-Mises の相当応力, $\sigma_{\mathrm{y} 0}$ は初期降伏 応力, $p$ は相当塑性ひずみ, $Q$ と $b$ は塑性硬化を表す ためのパラメータである. 塑性流動則は関連流れ則に 従うものとする. 


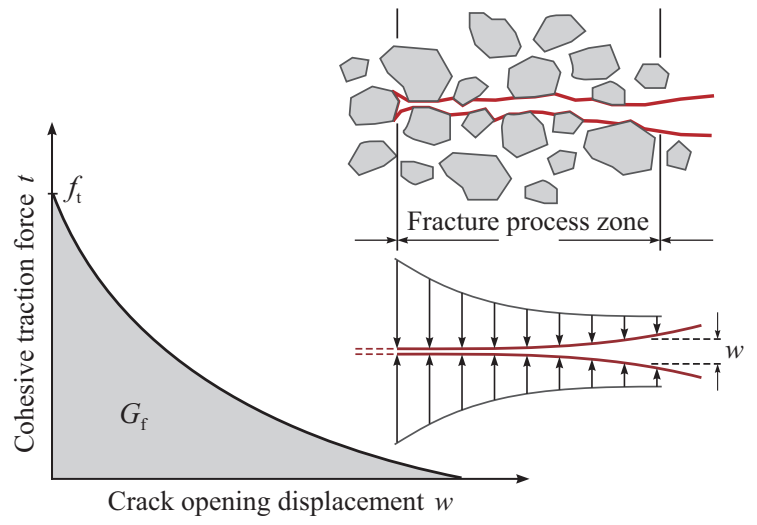

図-5 準脆性材料における結合力と開口変位の関係

c) コンクリートの材料モデル 17)

本研究では, 等方性の損傷モデルをコンクリートの 構成モデルに適用する。

$$
\sigma=(1-D) c: \varepsilon
$$

ここで， $D$ はスカラー值関数で表される損傷変数であ り， $0 \leq D \leq 1$ の範囲で損傷の度合いを表す。

損傷変数 $D$ の規定するに際し，本研究では，ひずみ テンソルと応力テンソルをスカラー量の等価ひずみと 等価応力に置き換え, 等価ひずみと等価応力の関係か ら，損傷変数を求めるモデル化を行う。等価ひずみに は, 次式で表される $\varepsilon_{\mathrm{e}}$ を適用する ${ }^{18)}$.

$$
\varepsilon_{\mathrm{e}}=\frac{k-1}{2 k(1-2 v)} I_{1}^{\prime}+\frac{1}{2 k} \sqrt{\left(\frac{k-1}{1-2 v} I_{1}^{\prime}\right)^{2}+\frac{12 k}{(1+v)^{2}} J_{2}^{\prime}}
$$

ここで, $v$ はポアソン比， $k$ は圧縮に強く引張に弱い特 性を付与できる圧縮引張強度比, $I_{1}^{\prime}$ は微小ひずみテン ソル $\varepsilon$ の第 1 不変量, $J_{2}^{\prime}$ は偏差ひずみテンソルの第 2 不変量である。

図-4に，主ひずみ空間に等価ひずみの等值面をプロッ トしたものを示す. 圧縮引張強度比により, 圧縮に強く 引張に弱いコンクリートの力学特性を表現できること がわかる.

本研究では, 破壊の進行（損傷の発展）のモデル化 に，コンクリートの破壊力学 19) に基づく方法を採用す る. 代表的な破壊力学パラメータである破壊エネルギー の概念に基づいて，図-5に示すような，ひび割れ境界 間における結合力と開口変位の関係 ${ }^{20)}$ を用いる.ここ で, $t$ は結合力, $w$ は開口変位, $f_{0}$ は破壊発生応力, $G_{\mathrm{f}}$ は破壊エネルギーである.

$$
t=f_{0} \exp \left(-\frac{f_{0}}{G_{\mathrm{f}}} w\right)
$$

1 次元問題に換算した等価ひずみ $\varepsilon_{\mathrm{e}}$ を用いて, 結合力 と開口変位を次のように書き換えることができる.こ

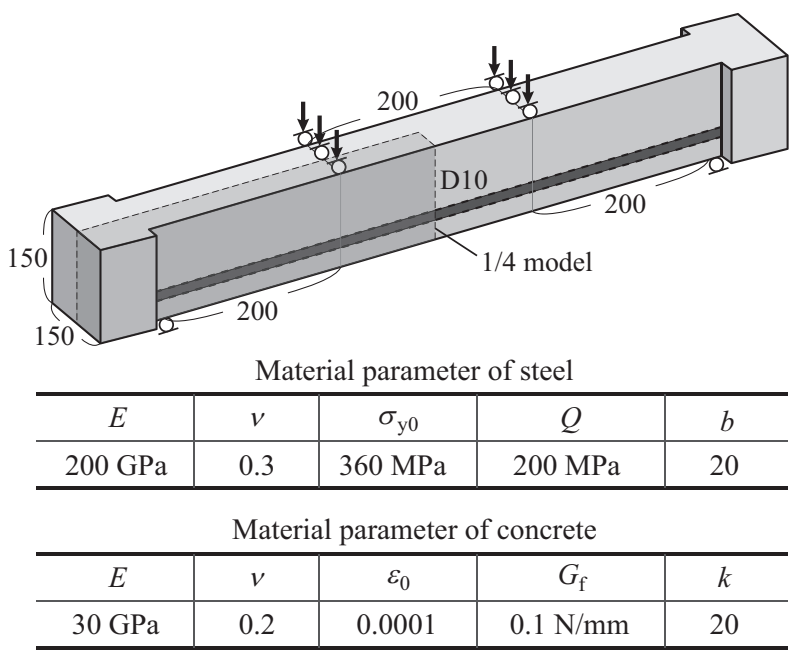

図-6 3 次元有限要素モデルと材料パラメータ

こで, $E$ はヤング率， $\sigma_{\mathrm{e}}$ は等価応力， $\varepsilon_{0}$ は破壊発生ひ ずみ， $h_{\mathrm{e}}$ は損傷を評価する領域の代表長さである.

$$
\begin{gathered}
t=E \varepsilon_{\mathrm{e}}=\sigma_{\mathrm{e}}, \quad f_{0}=E \varepsilon_{0} \\
w=\left(\varepsilon_{\mathrm{e}}-\varepsilon_{0}\right) h_{\mathrm{e}}
\end{gathered}
$$

この 3 式を式 (12)に代入することにより，コンクリー トの破壊力学を考慮した等価応力と等価ひずみの関係 は次のようになる。

$$
\begin{aligned}
\sigma_{\mathrm{e}} & =\left[1-\left(1-\frac{\varepsilon_{0}}{\varepsilon_{\mathrm{e}}} \exp \left(-\frac{E \varepsilon_{0} h_{\mathrm{e}}}{G_{\mathrm{f}}}\left(\varepsilon_{\mathrm{e}}-\varepsilon_{0}\right)\right)\right)\right] E \varepsilon_{\mathrm{e}} \\
& =\left[1-D\left(\varepsilon_{\mathrm{e}}\right)\right] E \varepsilon_{\mathrm{e}}
\end{aligned}
$$

これより, 損傷変数 $D\left(\varepsilon_{\mathrm{e}}\right)$ は次式で表される.

$$
D\left(\varepsilon_{\mathrm{e}}\right)=1-\frac{\varepsilon_{0}}{\varepsilon_{\mathrm{e}}} \exp \left(-\frac{E \varepsilon_{0} h_{\mathrm{e}}}{G_{\mathrm{f}}}\left(\varepsilon_{\mathrm{e}}-\varepsilon_{0}\right)\right)
$$

上式の $D\left(\varepsilon_{\mathrm{e}}\right)$ を用いて, 構成式 $(10)$ における損傷変数 $D$ を求めることができる. 過去に受けた損傷は回復しな いものとすると, 損傷変数 $D$ は減少しない関数となる.

本論文の数值解析では, 四面体要素を用いた有限要 素解析を適用する. 有限要素解析においては, 各々の 四面体要素が損傷を評価する領域になる。本研究では, 四面体 12 個で立方体 1 個を構成すると仮定し, 代表長 さ $h_{\mathrm{e}}$ を次式で定義する.

$$
h_{\mathrm{e}}=\left(12 V_{e}\right)^{1 / 3}
$$

ここで， $V_{e}$ は四面体要素の体積である.

\section{（2）内部ひび割れの再現性の検証}

解析対象は, 図-6に示すように，前節で示した図一 3 と同様の RC はりである. 鉄筋は SD345 の D10 異形 鉄筋とし, 四面体一次要素を用いて, 異形鉄筋の幾何 形状が再現できる程度のメッシュ分割を行う。問題の 対称性を考慮し，1/4 モデルによる数值解析とする. 1/4 モデルの要素数は約 130 万, 節点数は約 24 万である. 
t

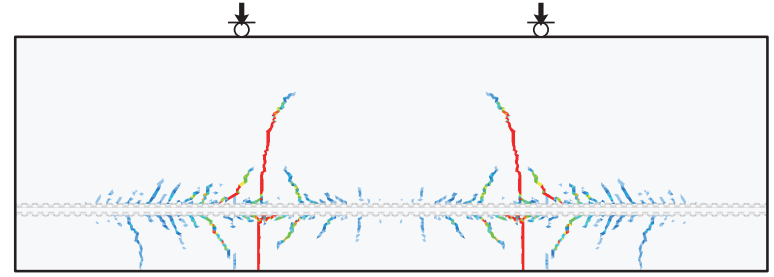

Displacement at loading point: $0.3 \mathrm{~mm}$

to

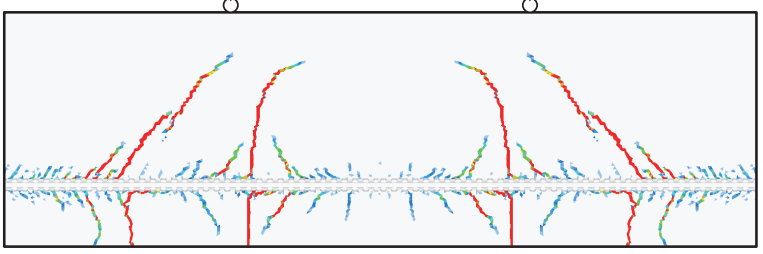

Displacement at loading point: $1.0 \mathrm{~mm}$ $+$

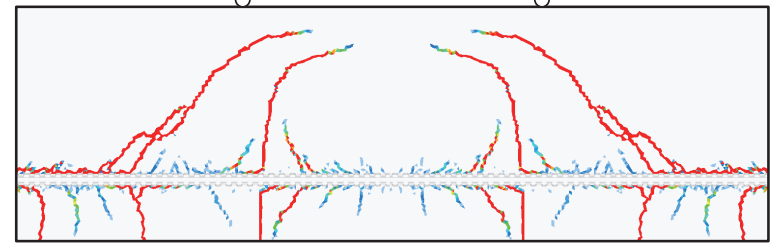

Displacement at loading point: $2.5 \mathrm{~mm}$

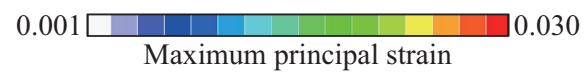

図-7 数值解析における鉄筋周辺の最大主ひずみ分布

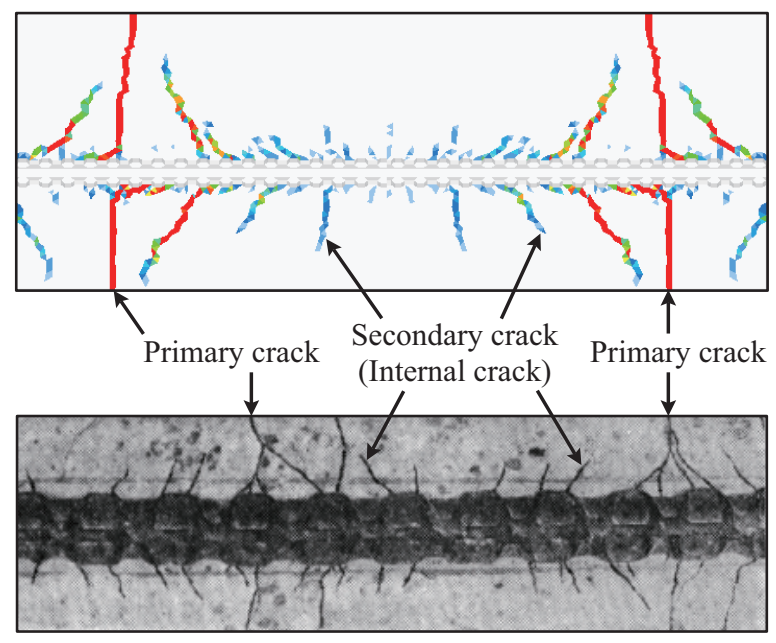

図-8 後藤ら 2) が実験で再現した内部ひび割れとの比較

鉄筋とコンクリートの材料パラメータは図-6に示す通 りとし, 変位制御による数值解析を行う.

数值解析結果として, 鉄筋を露出させた側面におけ る最大主ひずみ分布を図-7に示す，本研究では，ひず みの集中箇所をひび割れとみなしている. 本論文で提 案する試験体は部分的にかぶりが取り除かれているの で，かぶりのある実際の RC 部材とはやや異なる応力 状態となっているが，モデル表面に到達している大き なひび割れの周辺を見ると, 鉄筋から発生し, 斜め方

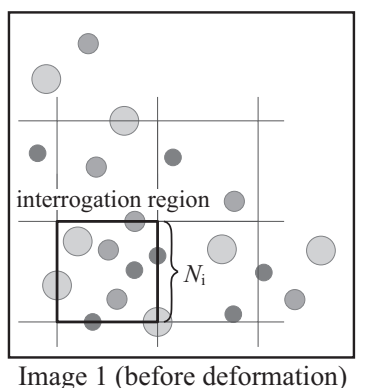

Image 1 (before deformation)

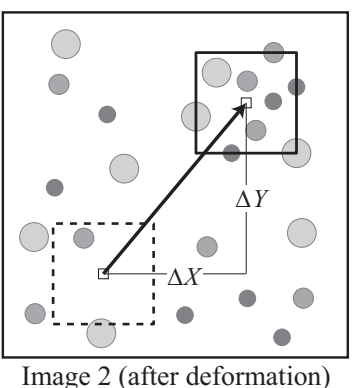

Image 2 (after deformation)

図-9 デジタル画像相関法の概要

向に進展する内部ひび割れが再現されている．鉄筋の 周辺を拡大した図-8 の結果と後藤らが実験で再現した 内部ひび割れを比較すると, 鉄筋周辺におけるひび割 れの発生状況がほぼ同様である，以上より，本論文で 提案する試験体および試験方法は, 試験体表面に内部 ひび割れを発生させる実験的方法として有効であると いえる.

\section{4. 実験・計測による検証}

実際に, 図-3 と同様の試験体を作成し，4点曲げ試 験を行い, 実験における内部ひび割れの再現性を検証 する.内部ひび割れは非常に小さく, 発生数も多いた め, 試験中に内部ひび割れの発生と進展を計測するの は容易ではない，そこで本研究では，目視できない微 細なひび割れであっても計測が可能な画像解析 ${ }^{15)}$ を用 いて, 試験中における内部ひび割れの計測を行う.

\section{(1) デジタル画像相関法}

本研究で用いる画像相関法は, 図-9に示すように, 変 形前の画像を検査領域と呼ばれる小領域に分割し, 検 查領域内の輝度值パターンが類似している領域を変形 後の画像から探し出すことで, 検査領域の平均移動量 を算出する方法である. 輝度值パターンの類似性の評 価には, 次式で表される相互相関関数 ${ }^{21)}$ を用いる.

$$
\begin{aligned}
& R(\Delta X, \Delta Y) \\
& =\frac{\sum_{i=1}^{N_{i}} \sum_{j=1}^{N_{i}} f\left(X_{i}, Y_{j}\right) g\left(X_{i}+\Delta X, Y_{j}+\Delta Y\right)}{\sqrt{\sum_{i=1}^{N_{i}} \sum_{j=1}^{N_{i}} f\left(X_{i}, Y_{j}\right)^{2} \sum_{i=1}^{N_{i}} \sum_{j=1}^{N_{i}} g\left(X_{i}+\Delta X, Y_{j}+\Delta Y\right)^{2}}}
\end{aligned}
$$

ここで, $N_{\mathrm{i}}$ は検查領域の大きさ, $\Delta X$ は $X$ 方向の移動 量, $\Delta Y$ は $Y$ 方向の移動量であり, それぞれ図-9に図解 されている. $f(X, Y)$ は第一画像の輝度值関数, $g(X, Y)$ は第二画像の輝度值関数である. 


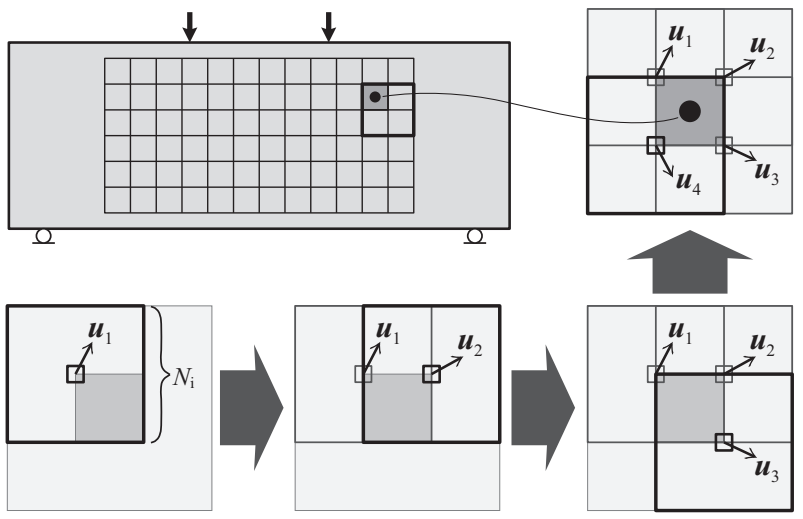

図-10 検査領域の配置方法と計測される変位ベクトル

\section{a）変位ベクトルの計測}

検査領域を画像内で一定の正方形とすると，図-10に 示すように，正方格子状に変位ベクトルを計測するこ とができる．画像相関法では，検査領域を小さくする と, 計測される変位分布は高解像度になるが, 輝度値 パターンの個性がなくなり, 相関がとれなくなるので, 計測精度は低下する，逆に，検査領域を大きくすると， 計測精度は高くなるが, 計測される変位分布の解像度 が下がる. 本研究では, 図-10に示すように, 正方形の 検査領域を半領域ずつ重複させて配置することにより， 検査領域を小さくせずに，また計測点の解像度も下げ ずに，変位ベクトルを計測する方法を採用する.

デジタル画像上で単純に相関を評価するだけでは, 整 数画素単位の変位ベクトルしか求まらない，本研究で は，1 pixel 未満の精度で変位ベクトルを計測するため に，関数近似による簡易なサブピクセル解析を導入す る. 具体的には，ガウス関数を利用して，次式により 相関が極大值となる位置 $X_{\text {sub }}$ を予測する.

$$
X_{\text {sub }}=X_{i}-\frac{1}{2} \frac{\ln R_{i+1}-\ln R_{i-1}}{\ln R_{i+1}-2 \ln R_{i}+\ln R_{i-1}}
$$

ここで， $X_{i}$ は整数画素単位で相関が最大となる位置, $X_{i-1}$ と $X_{i+1}$ はその両隣の位置, $R_{i}, R_{i-1}, R_{i+1}$ はそれぞ れ位置 $X_{i}, X_{i-1}, X_{i+1}$ における相関值である.

\section{b) ひずみテンソルの算出}

図-10に示すように，正方形の検査領域を設けると， 正方格子状に変位ベクトルを計測することができる．本 研究では, 計測された変位ベクトルからひずみを評価 する方法として, 次式で表される四角形有限要素の変 位一ひずみ関係式を用いて, 各要素の中心点（図-10の ・印）でのひずみを算出する.

$$
\boldsymbol{\varepsilon}_{e}=\boldsymbol{B}_{e} \boldsymbol{u}_{e}
$$

ここで， $\boldsymbol{\varepsilon}_{e}$ は $\varepsilon_{x}, \varepsilon_{y}, \gamma_{x y}$ を縦に並べたフォークト表記 によるひずみべクトル， $\boldsymbol{B}_{e}$ は双一次四角形有限要素の B マトリックス（変位一ひずみマトリックス）, $\boldsymbol{u}_{e}$ は

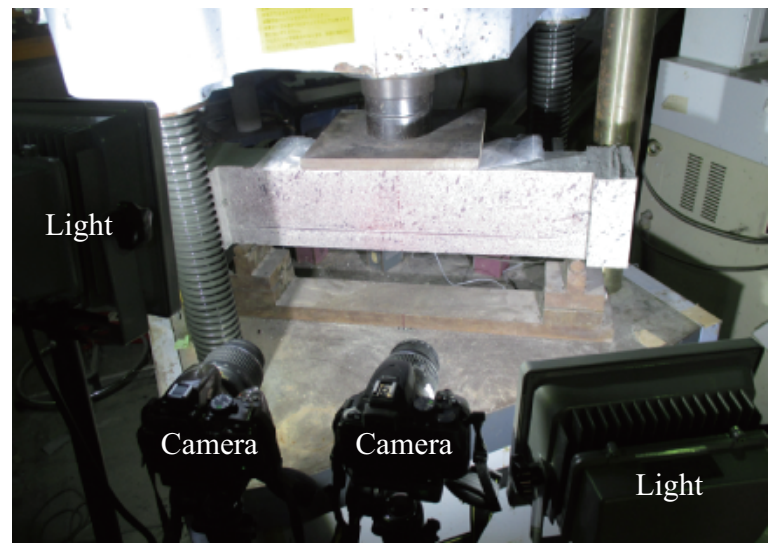

図-11 試験と撮影の様子

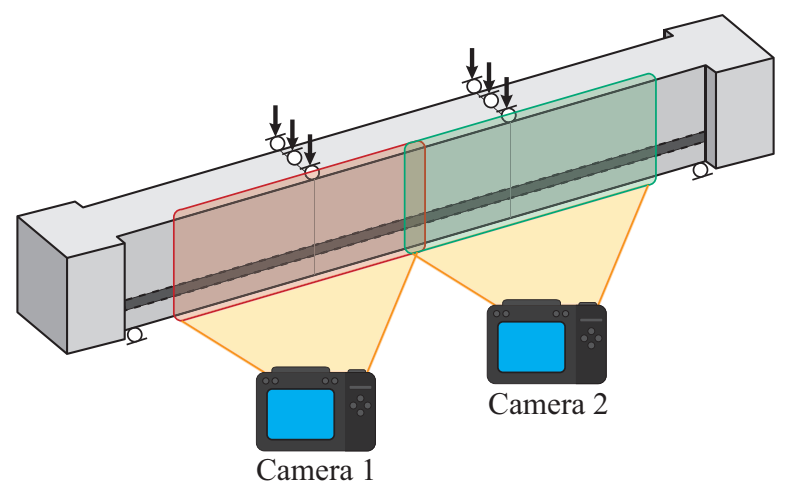

図-12 2 台のカメラによる試験体の撮影範囲

図-10の $u_{1} \sim u_{4}$ を縦に並べた変位ベクトルである.

\section{(2) 内部ひび割れの実験と計測}

\section{a) 実験・計測の条件}

実際に，図-3 と同様の試験体を作成し，4点曲げ試験 を行い，デジタル画像相関法を用いて内部ひび割れの 計測を行った。試験体の作製に使用したコンクリートの 配合は, 水セメント比 $48 \%$, 単位水量 $284 \mathrm{~kg} / \mathrm{m}^{3}$, 単 位セメント量 $591.7 \mathrm{~kg} / \mathrm{m}^{3}$, 単位細骨材量 $1234.0 \mathrm{~kg} / \mathrm{m}^{3}$ である．鉄筋を露出させた特殊な RC はりに引張が適 切に作用するかどうかを確認するため，はり中央にお ける鉄筋の内側の側面にひずみゲージを貼付した.

試験および撮影の様子を図-11に示す。試験体の広範 囲を精度よく計測するために，デジタル画像の撮影に は 2400 万画素のデジタル一眼レフカメラを 2 台使用し， 撮影する範囲は, 図-12 に示すように, 試験体の中央か ら左右に $275 \mathrm{~mm}$ ずつ, 計 $550 \mathrm{~mm}$ の範囲とした。撮 影の明度を一定に保つため, 照明には LED 投光器を使 用し，画像相関の精度を上げるため，試験体の撮影面 にスプレーでランダム模様をつけた。撮影は 2 秒毎に 1 枚とし，載荷速度は $4 \mathrm{kN} / \mathrm{min}$ とした。 


\section{b) 実験・計測の結果}

実験結果として，鉄筋に貼付したひずみゲージの值 は，最大荷重点において $1800 \mu$ 程度であった。鉄筋は 脱落することなく, 面外方向にほとんど変形していな いので，曲げ試験により鉄筋には引張が適切に作用し ていたといえる.

次に, デジタル画像相関法により計測した最大主ひず みの分布を図-13に示す．検査領域サイズ $N_{\mathrm{i}}$ を 70 pixel とし, 前節で示した図-7 の数值解析結果に合わせて, 結 果を可視化している. 本研究では，ひずみの集中箇所 をひび割れとみなしている。計測結果を見ると, 数值 解析結果と同様に，比較的大きな 1 次ひび割れ（曲げ ひび割れ）が生じており, 数值解析ほど鮮明ではない ものの，鉄筋の近傍から内部ひび割れが発生し，1 次ひ び割れに向かって斜め方向に進展していることがわか る. 実験中に, 目視ではひび割れを確認できなかった が，画像解析でははっきりと内部ひび割れを計測でき ている. 内部ひび割れのひずみの值は, 1 次ひび割れと 比べて小さな值となっている。 これは, 内部ひび割れ が曲げによる試験体の直接的な変形によるものではな く，曲げによって生じた引張による副次的なひび割れ であることを意味している。

以上より, 内部ひび割れの再現と計測を可能とする 実験的方法として, 本論文で提案する試験体および試 験方法が有用であることを示した。 なお，本研究では， 内部ひび割れの発生状況を確認するために, デジタル 画像相関法による全視野計測を適用したが，マイクロ スコープ等により開口幅を計測すれば, 内部ひび割れ の特徵をより詳細に調べることができる.

\section{5. おわりに}

鉄筋コンクリートに発生するひび割れのなかには, 鉄 筋の近傍から発生し, 部材表面には現れない「内部ひ び割れ」が存在する. 表面に現れるひび割れと同様に, 内部ひび割れも水やイオンの移動を加速させることが 確認されている.これまでに示されている内部ひび割 れの計測方法の多くは, 試験体内部に着色のためのイ ンクを注入する方法であり, 内部ひび割れを確認する には試験後に試験体を切断しなければならない.

本論文では, 試験中に内部ひび割れの発生状況や進 展度合を計測するために，かぶりを取り除いて鉄筋を 露出させた試験体とその試験方法を提案した.まず，ひ び割れの 3 次元幾何形状を再現できる数值解析を用い て, 内部ひび割れの再現に適した試験体および試験方 法であることを検証した。そして, 実際に試験体を作 成し, 曲げ試験を行い, デジタル画像相関法を適用し て, 試験体側面のひずみ分布を計測した。その結果, 試

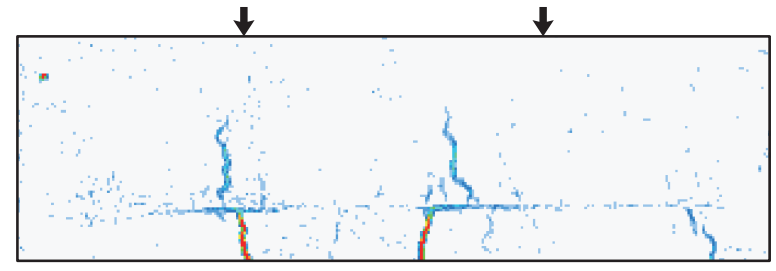

Displacement at loading point: $0.3 \mathrm{~mm}$

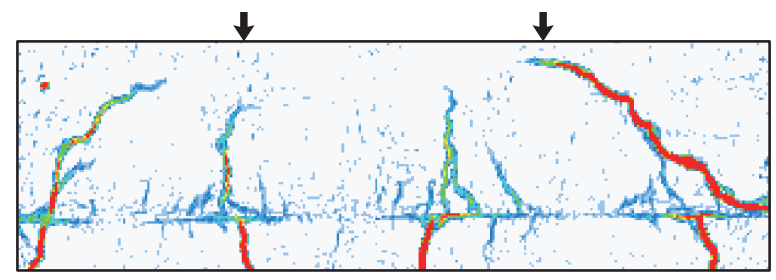

Displacement at loading point: $1.0 \mathrm{~mm}$

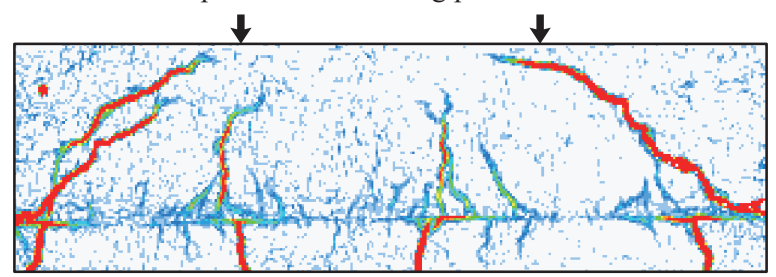

Displacement at loading point: $2.5 \mathrm{~mm}$

0.001

Maximum principal strain

図-13 画像解析における鉄筋周辺の最大主ひずみ分布

験中において, 内部ひび割れの発生と進展を可視化す ることができ, 載荷過程における内部ひび割れの発生 状況や進展度合を計測可能であることを示した。

本論文では，鉄筋を露出させた試験体を用いること で，内部ひび割れの発生と進展を計測できることを示 したが，実際の RC 部材における鉄筋周辺の応力状態 を厳密には再現していない. 今後は, かぶりの有無に よる力学的な影響を検討し, 内部ひび割れの再現精度 を高める必要がある.

謝辞：本研究は, JSPS 科研費 $16 \mathrm{~K} 17549$ の助成を得 て行われました。

\section{参考文献}

1) 土木学会 (編) : 2012 年制定コンクリート標準示方書 [設 計編], pp.148-150, 2012.

2) 後藤幸正, 大塚浩司 : 引張を受ける異形鉄筋周辺のコン クリートに発生するひびわれに関する実験的研究, 土木 学会論文報告集, 第 284 号, pp.85-100, 1980.

3) 氏家 勲, 小林清和, 佐藤良一, 長瀧重義 : 内部ひび割 れを有するかぶりコンクリートの塩分浸透性に関する 研究, コンクリート工学年次論文報告集, Vol.14, No.1, pp.843-848, 1992.

4) 氏家勲, 佐藤良一, 長瀧重義 : 内部ひび割れに起因する かぶりコンクリートの密実性低下の透気性による検討, 土木学会論文集, Vol.1996, No.550, pp.163-172, 1996.

5) Michel A, Solgaard AOS, Pease BJ, Geiker MR, Stang H, Olesen JF: Experimental investigation of the relation between damage at the concrete-steel interface and initiation 
of reinforcement corrosion in plain and fibre reinforced concrete, Corrosion Science., Vol.77, pp.308-321, 2013.

6) Goto Y: Cracks formed in concrete around deformed tension bars, ACI Journal, Vol.68, pp.244-251, 1971.

7) 角田与史雄 : 鉄筋コンクリートの最大ひび割れ幅, コン クリートジャーナル, Vol.8, No.9, pp.1-10, 1970.

8) 丸山一平，佐藤良一: 超高強度コンクリートを用いた RC 部材中の鉄筋近傍における微細ひび割れの発見, 日本建 築学会構造系論文集，Vol.72, No.617,pp.1-7, 2007.

9) 林和彦, 椿 龍谷, 細田 暁 : 鉄筋コンクリート部材の鋼 材腐食に及ぼす曲げひび割れの内部構造の影響, 土木学 会論文報告集 E，Vol.65, No.4, pp.577-588, 2009.

10) 大塚浩司, 武田三弘：X 線造影撮影によるコンクリート 構造物内部のひび割れ検出技術の開発に関する研究，土 木学会論文集, Vol.58, No.725, pp.143-156, 2003.

11）池田尚治 : 鉄筋コンクリート部材における鉄筋とコンク リートとの応力伝達に関する研究, 土木学会論文報告集, 第 307 号, pp.85-97, 1981.

12）三村陽一, 吉武勇, 森本公典, 浜田純夫 : 若材齢コンク リートと異形鉄筋の局部付着特性に関する実験的研究, 土木学会論文集, Vol.63, No.3, pp.410-423, 2007.

13）岡崎 慎一郎, 車谷麻緒, 氏家 勲, 高本直樹 : 内部ひび割 れを可視化するための新奇な手法の提案，コンクリート 工学年次論文集, Vol.36, No.1, pp.406-411, 2014.

14) 車谷麻緒, 根本優輝, 相馬悠人, 寺田 賢二郎 : コンクリー トの破壊力学を考慮した鉄筋コンクリートの 3 次元破壊
シミュレーションとその性能評価, 日本計算工学会論文 集, Vol.2016, pp.20160004, 2016.

15）車谷麻緒, 松浦 遵, 根本忍, 点 智深: コンクリートのひび 割れ進展計測のため画像解析手法に関する基礎的研究，土 木学会論文集 A2（応用力学）, Vol.70, No.2, pp.135-144, 2014.

16) Dunne F, Petrinic N: Introduction to Computational Plasticity, Oxford University Press, 2005

17）車谷麻緒，寺田 賢二郎，加藤準治，京谷孝史，樫山和男： コンクリートの破壊力学に基づく等方性損傷モデルの定 式化とその性能評価, 日本計算工学会論文集, Vol.2013, pp.20130015, 2013.

18) de Vree JHP, Brekelmans WAM, van Gils MAJ: Comparison of nonlocal approaches in continuum damage mechanics, Comput. Struct., Vol.55, pp.581-588, 1995.

19) Hillerborg A, Modéer M, Petersson PE: Analysis of crack formation and crack growth in concrete by means of fracture mechanics and finite elements, Cem. Concr. Res., Vol.6, pp.773-782, 1976.

20) Wells GN, Sluys LJ: Application of embedded discontinuities for softening solids, Engng. Fract. Mech., Vol.65, pp.263-281, 2000.

21）可視化情報学会 (編):PIV ハンドブック，森北出版，2002.

(2017. 6. 23 受付)

\title{
EXPERIMENTAL AND NUMERICAL STUDY ON VISUALIZING INTERNAL CRACKS IN REINFORCED CONCRETE
}

\author{
Mao KURUMATANI, Norikazu HENMI and Shinichiro OKAZAKI
}

We propose a test specimen and its test method for measuring and visualizing internal cracks in reinforced concrete, and demonstrate the validity. The proposed test specimen is a RC beam with steel bars exposed partially, which enables us to measure the internal cracks formed around deformed bars. We first show a numerical example to demonstrate the validity of the proposed test method for measuring internal cracks, using the finite element analysis with a damage model based on fracture mechanics for concrete. Then, the propagation of internal cracks in 4-point bend test of the proposed test specimen is measured and visualized by the digital image correlation. The comparison between the numerical and experimental results shows that the proposed test method is effective for measuring and visualizing internal cracks in the process of loading test. 